УДК 338.245(100)(09)

ББК 65.54-981Г

DOI 10.17150/2308-2588.2017.18(2).330-356

Г. Г. Попов

Московский технологический институт, Финансовый университет при Правительстве РФ, г. МоскВа, Российская Федерация

\title{
СОЮЗНИКИ НАЦИСТСКОЙ ГЕРМАНИИ И РАЗРУШЕНИЕ ЕДИНСТВА ПОСИП: СТРАНИЦЫ ЭКОНОМИЧЕСКОЙ ИСТОРИИ ВТОРОЙ МИРОВОЙ ВОЙНЫ
}

Аннотация. В статье на примерах Италии и Испании рассматривается вопрос о разрушении западными союзниками военно-политического блока «Ось». Автор утверждает, что нацистский блок к концу 1943 г. был в состоянии противопоставить силам союзников не более трех миллионов солдат и офицеров из-за выхода из войны Италии и нейтралитета Испании, воздержавшейся от вступления в конфликт на стороне Германии.

Ключевые слова. Государства «Оси», нефтяное эмбарго Испании, режим Франко, фашизм в Италии, военная экономика.

G. G. Popov

Moscow Technology Institute, Financial University under the Government of the Russian Federation, Moscow, Russian Federation

\section{ALIIES OF NAZI GERMANY AND BREAKUP OF THE AXIS:

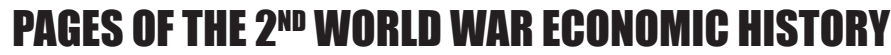

Abstract. The article considers the problem of destruction of the military-political bloc «Axis» by the Allies on the example of Italy and Spain. The author states that in 1943 Nazi bloc had no more than 3 million of soldiers and officers because of Italy disengagement and Spain neutrality that did not enter the war to support Germany. 
Keywords. «Axis» states, oil embargo of Spain, Franco regime, fascism in Italy, war economy.

\section{Введение}

Мы обращаемся к сложной теме, имеющей прямое отношение к деятельности вооруженных сил, разведок и дипломатии западных союзников в годы Второй мировой войны, направленной на разрушение созданной Гитлером системы под названием «Ось». Само это название - «Ось» - подразумевало объединение государств, расположенных географически в рамках Евразийского континента. География сыграла важную роль в судьбе этого военно-политического блока. Формирование союзнических отношений нацистской Германии с другими государствами носило более сложный характер, нежели образование Антигитлеровской коалиции. Италия имела все шансы длительное время оставаться нейтральной, либо не вступить в войну вовсе, повернись дела Гитлера во Франции в другое русло в мае 1940 г. Япония имела союзнические отношения с нацистским режимом фактически только против западных союзников. Это отличает «Ось» от военно-политического блока «Центр», противостоявшего державам «дружественного соглашения» (Антанте) в годы Первой мировой войны: входившие в него государства воевали против всех общих врагов, а не избирательно. Румыния была не настроена воевать против западных союзников, о чем открыто дал понять на встрече в Зальцбурге в апреле 1943 г. ее лидер маршал Антонеску. Придерживался ли Карл Маннергейм стратегии ограниченного союза с Германией - спорный вопрос. Однако надо отметить, что Финляндия технически не могла вести борьбу с союзниками, и вопрос об участии ее войск в войне не обсуждался.

Что касается режима Виши во Франции, то его можно назвать слабым звеном «Оси», которое так и не преобразовалось в полноценного союзника Германии 2017. T. 18 , № 2. C. 330-356 
из-за ряда случайных обстоятельств, вызванных операцией войск США в Северной Африке в конце 1942 года. Испания не стала полноценным участником блока «Ось» из-за политических противоречий между Франко и Гитлером и слишком сильной зависимости от экономики США. И это отличает «Ось» от блока «Центр», в рамках которого участники не были изначально зависимы от США и других государств Запада. Гитлер стремился превратить режим Виши в полноценного военного союзника, но для этого надо было соблюсти видимость уважения к остаткам суверенитета Франции, и этой «видимостью» стало сохранение колоний, пункт, из-за которого французские ультраправые готовы были блокироваться с германскими нацистами. В этой связи претензии Франко на французскую часть Марокко были отвергнуты Гитлером в конце 1940 года, что стало проблемой номер один в германо-испанских отношениях.

В данной статье мы ставим задачу установления роли западных союзников в ослаблении связей внутри системы «Ось», а также последствий их действий для военной ситуации в целом.

\section{Италия - слабое звено ॥Осищ?}

Долгие годы на Западе и в России Италия рассматривалась как слабое звено «Оси», и не только в силу недостатков ее экономической системы, но также изза моральной слабости армии. Как показали, однако, Д. Садкович и Э. Гриблинг [8], «трусость» итальянцев и их нежелание сражаться были очередным мифом, созданным американскими военными. Вторым мифом стало техническое отставание Италии - страны, имевшей к началу Второй мировой войны вторые по мощи в Европе ВВС и один из мощнейших флотов мира, а также вторую в континентальной Европе автомобильную промышленность. Ее поражение в Греции в 1940 году было вызвано погодными условиями и плохой ло- 
гистикой в Албании. Италия не готовилась к вступлению в войну против западных союзников, так как Муссолини не был уверен, что на такой конфликт пойдет его союзник Гитлер [10]. Правда, Макгрегор Нокс в своих трудах доказывает, что итальянский фашизм породил невежество и национальное высокомерие среди итальянской военной элиты, что в итоге негативным образом сказалось на руководстве военными операциями, но нам надо вспомнить в этой связи, что фашистская Италия была не одинока в этом смысле.

Принижение значения Италии как игрока на военной сцене мира искажает и истинные военные достижения Красной армии в конце 1942 года на Дону, когда советские войска разбили Восьмую итальянскую армию, действуя в буквально экстремальных природных условиях. Надо сказать, что, в отличие от западных союзников, режим Муссолини, что присуще фашистским режимам вообще, уделял приоритетное внимание оснащению армии. В 1938 году в Италии была запущена программа перевооружения артиллерии, которая обошлась бюджету в 5 млрд лир (огромные, по европейским меркам того времени, деньги) и завершилась в 1941 году (судя по всему, в этом году Муссолини и планировал полностью перевооружить свою армию, по возможности избегая участия в крупных конфликтах). Несколькими месяцами позже в Италии была начата программа перевооружения истребительной авиации. В 1930 годы Италия отказалась от кавалерии в пользу моторизированной пехоты, что потребовало конструирования более совершенного армейского грузовика [8, р. 16-17]. Правда, итальянская армия оказалась в годы войны одной из самых низко моторизованных в мире.

В августе 1940 года американские эксперты пришли к выводу, что экономика Италии продержится еще не более трех месяцев. Вступление Италии в войну было во многом вызвано стремлением Муссоли2017. T. 18 , № 2. C. $330-356$ 
ни оказаться в числе победителей. Как ни странно, но одним из результатов поражения Франции в 1940 году стало неудачное вступление в конфликт Италии, что в немалой степени осложнило положение «Оси» годом позднее. Разумеется, Муссолини не предполагал, что Англия откажется от мирных переговоров, и Гитлер нападет на СССР.

Итак, представим себе, что министр иностранных дел Италии граф Чиано убедил в конце 1939 года Н. Чемберлена, что Италия будет придерживаться строгого нейтралитета, как ему удавалось это делать до этого. Разумеется, от англичан требовались в таком случае уступки в Африке и сохранение поставок стратегического сырья, в особенности черных металлов. Этого и хотел добиться министр иностранных дел Италии в декабре 1939 года, но крайне безуспешно [10, p. 30]. В таком случае Италия могла сохранить довоенный уровень потребления угля в объеме 15,1 млн т, тогда как фактический его объем составил 4,4 млн. При таком уровне потребления угля итальянская промышленность могла в 1940-1941 гг. поддерживать выпуск военной техники на более высоком уровне. К тому же, отсутствие английского эмбарго на поставки черных металлов позволило бы Италии сохранить их потребление на уровне 4,6 млн т в год, а не 2,3 млн, как это было фактически.

Мы с большой долей уверенности можем сказать, что при сохранении в 1940-1941 гг. ситуации «плохого мира» между Италией и Британией первая могла бы выпустить вдвое больше военной продукции, нежели это имело место в действительности. При этом мы даже не учитываем возможных немецких поставок, которые могли идти в обмен на итальянские фрукты и бокситы. Но пока что остановимся на том варианте, что немецкий импорт отсутствует. В этом случае Италия вполне смогла бы осилить в 1940-1941 гг. выпуск почти 3000 танков и 12000 самолетов, а также 9000 артилле- 
рийских систем (в два раза больше фактического, притом, что металла должно было поступить также в два раза больше). Италия в эти годы располагала порядка 4,4 млн промышленных рабочих, к которым режим Муссолини мог добавить более миллиона мобилизованных сельских жителей [9, р. 45-46] ${ }^{1}$. Принимая во внимание, что в нацистской Германии было в начале войны с СССР 10,5-11 млн индустриальных рабочих и служащих, военная экономика Италии не имела дефицита рабочей силы.

Теперь, представим себе, что Италия вступает в войну в середине лета 1941 года после решения дуче поддержать Гитлера в борьбе с большевистской Россией. Несомненно, к сентябрю-октябрю 1941 г. это ведет к разрыву отношений с Англией, которая в конце августа в лице Черчилля принимает решение сражаться в коалиции с Советским Союзом, хотя, конечно, коалиция возникла в ходе Московской конференции. При таком развитии событий Италия оказывается в состоянии развернуть против своих противников уже достаточно оснащенную для войны армию. Итальянский средний танк М 13/4 [9, р. 41-42] $]^{2}$ практи-

1 Макгрегор Нокс считает организацию производства в промышленности Италии того времени отсталой, но мы должны принять во внимание, что и организация труда в других странах была не на высоте, если хотя бы вспомнить немецкие методики, опиравшиеся на личные опыт и смекалку мастеров-ветеранов производства. В отличие от континентальной Европы, американские компании под влиянием Генри Форда еще в конце Первой мировой войны перешли к жесткой стандартизации производственных процессов, этот опыт перенял СССР в период Первой пятилетки, что стало одной из причин советского экономического чуда в годы Великой Отечественной войны.

2 Трудно согласиться с мнением Нокса, что итальянская бронетехника была ущербной. Если бы дело обстояло именно так, то германские власти, оккупировавшие Италию осенью 1943 г., отказались бы от заказов для своих войск итальянских средних танков. Однако «Фиат» продолжал до 1945 года снабжать немецкие войска и силы Республики Соло в Италии именно танками итальянских моделей. Ничего подобного не было в отношении 2017. T. 18, № 2. С. 330-356 
чески не уступал британскому «Crusader», итальянский фронтовой истребитель МС 202 был эквивалентен по качеству британскому Spitfire [10, p. 48]. Таким образом, Италии не потребовалось бы приглашать в Северную Африку корпус Роммеля, и этот генерал поехал бы на Восточный фронт вместе с десятками тысяч солдат и офицеров вермахта, которые при фактическом развитии событий оказались задействованы в Африке. По нашим оценкам, сделанным в других работах, Северная Африка поглотила около 2000 танков «Оси», из которых почти половина была немецкими, не считая потерь итальянцев до высадки группировки Роммеля в Триполи в феврале 1941 года и немецко-итальянских потерь во время операций в Тунисе в первом полугодии 1943 года. Помимо танков, на Восточный фронт в таком случае были бы от-

французских танков, вермахт изредка применял только трофейные французские модели, не настаивая на выпуске во Франции новой бронетехники. Что касается клепаной брони, в чем Нокс упрекает инженеров «Фиат», то это была особенность многих моделей танков Второй мировой войны. Эффективность бронетехники заключалась не столько в прочности брони, сколько в пробивной силе противотанковых снарядов, оптике и дальности стрельбы орудия. Историки упрекали Муссолини и администрацию «Фиат» за отказ принять на вооружение немецкий Т3, запчасти к которому готова была поставлять Германия, однако надо вспомнить в этой связи негативный опыт строительства бронетанковых войск в Румынии, когда немцы не выполнили полностью и вовремя своих обязательств перед Антонеску по поставкам танков и САУ. Румынским танкистам приходилось сражаться на малочисленных советских трофейных образцах, которые в очень ограниченном количестве передавал им вермахт. К тому же, модель Т 3 была уже в 1940 г. морально устаревшей, являя собой переходный тип от легкого к среднему танку. То же самое касается истребителя «Мессершмидт», итальянские инженеры уже в Испании заметили, что этот истребитель обладает серьезными недостатками, по сути, это был спортивный самолет, переделанный в истребитель. В этой связи инженеры «Фиата» приняли вполне мудрое решение - взять за образец трофейный советский Т-34 для дальнейших разработок собственного среднего танка, когда Г. Гудериан продолжал доказывать перед Гитлером высокую эффективность Т4. 
правлены сотни бомбардировщиков и истребителей люфтваффе.

Но Британия в 1939 году имела свои планы относительно Италии, Лондон перебрасывал в зону Средиземного моря войска и ресурсы. Эмбарго на поставки металлов наносили сильный ущерб итальянской экономике. Таким образом, именно Англия, еще руководимая Н. Чемберленом, ускорила вступление Италии в войну, что стало выгодным для Антигитлеровской коалиции фактом. В противном случае Британию в Африке ожидал, скорее всего, разгром, а Советскому Союзу пришлось бы сражаться дополнительно с почти миллионом итальянских солдат уже примерно в августе или сентябре 1941 года [9, р. 33]³. По качеству итальянские войска, как утверждает Д. Д. Садкович, не уступали, либо незначительно уступали, немецким. С этим утверждением, конечно, можно поспорить, но итальянская армия все-таки была, по своей сути, западноевропейской, пусть и со многими недостатками: немецкие были лишь лучше оснащены [10]. С введением такой детерминанты как импорт ресурсов из Германии, возможности военного производства режима Муссолини возрастали в 1940-1941 годы минимум на 30 процентов. Нетрудно представить, что при контрфактической модели - «плохой мир» Италии с Британий плюс импорт из Германии $[9, \text { р. 46 }]^{4}-$ у Италии

3 Режим Муссолини не мог поставить под ружье более миллиона итальянцев, что было вызвано экономическими ограничениями.

${ }^{4}$ М. Нокс утверждает, что немцы нашли в северной Италии залежи стратегического сырья осенью 1943 г., когда пал режим Муссолини и страна была оккупирована вермахтом. Отсюда он делает вывод, что главной трудностью для мобилизации итальянской экономики был не дефицит сырья, но плохая организация производства. Мы сомневаемся, что запасы сырья на севере Италии были реально крупными в конце 1943 г., к тому же, они стали результатом роста импорта немецкой, французской (импорт из вишистской Франции) и румынской продукции в 1942 - начале 1943 г., когда Италия в обмен отправляла в эти страны продоволь2017. T. 18, № 2. С. 330-356 
были все шансы успешно противостоять не только Англии в Африке в 1942 году, но даже и американским силам, высадившимся на этом континенте [9, p. 45] (конечно, десант в Марокко мог в таком случае и с большой долей вероятности вовсе не состояться).

Разумеется, можно возразить, что в ответ на увеличение итальянского выпуска вооружений англо-американский альянс должен был ответить наращиванием собственного выпуска вооружений. Это так, но мы должны учесть ограничения военных экономик Британии и США, а также ограниченные возможности по развертыванию в Северной Африке боевых соединений западных союзников. Эта тема требует отдельного анализа.

Теперь скажем несколько слов о тех силах нацистской Германии, какие были отвлечены для обороны Италии после проведения высадки на Сицилии войск союзников. Мы опираемся в этом вопросе исключительно на немецкие трофейные документы. Вопрос с военным потенциалом на других, кроме Восточного фронта, театрах военных действий до высадки в Нормандии остается достаточно спорным, поскольку качественные характеристики дивизий вермахта различались даже в рамках одного театра военных действий. По данным Верховного главнокомандования вермах-

ствие. Когда итальянские военные предприятия были включены в состав немецкой военной промышленности, эти «огромные залежи сырья» куда-то исчезли и итальянские промышленники довольствовались скудными поставками из Германии.

${ }^{5}$ Нокс считает японскую модель военной экономики более эффективной, потому что Япония, имея промышленный потенциал в два раза ниже, чем Италия, смогла произвести в несколько раз больше боевых самолетов. Здесь можно возразить, что Японии не требовалось создавать такого большого количества сухопутных дивизий, в 1942 году японским войскам удалось захватить в Юго-Восточной Азии много военной техники и транспортных судов, что снизило нагрузку на военную промышленность Японской империи, и в этих условиях можно было осуществлять выпуск большого количества самолетов. 
та, в Италии на момент крушения режима Муссолини были развернуты 17,5 немецких дивизий․ Разумеется, до появления предпосылок отставки Муссолини Италия не была так насыщена германскими войсками. Надо сказать, что под влиянием Йодля Гитлер согласился на переход в Италии к глухой обороне, чтобы сэкономить силы для борьбы на Восточном фронте. Однако наращивание Эйзенхауэром сил в Италии после проведения успешной высадки на Сицилии (операция «Хаски») заставила командование начать переброску ударных соединений в Италию.

По состоянию на 31 января 1944 г. вермахт располагал в Италии только танковыми, моторизованными и панцергренадерскими дивизиями в следующем составе: 3 (танковая), 15 (панцергренадерская), 29 (панцергренадерская), 90 (панцергренадерская), 26 (танковая), «Герман Геринг» (танковая). Кроме того, танковые подразделения были приданы 2-й охранной дивизии (словаки), 71-й и 44-й пехотным дивизиям‥ И это дает нам в сумме 9 дивизий, находившихся в активной фазе боевых действий на зиму 1944 г. в Италии. Но, учтем, что вермахт не планировал активных наступательных действий в Италии, что было вызвано как ситуацией на Восточном фронте, так и логистическими сложностями снабжения германских войск, а также невозможностью обеспечить надежной береговой обороной открытые фланги германской группировки в Италии. Именно открытость флангов для морских десантов сильно подведет германские войска в Италии в 1944 году.

Немецкие войска несли большие потери в бронетехнике во время боев в Италии. Вместе с бронетехникой в пехотных дивизиях германская группировка войск в Италии на 31 января 1944 г. имела 196 Т4, 106 Т3,

${ }^{6}$ Центральный архив Министерства обороны Российской Федерации (ЦАМО РФ). Ф. 500. Оп. 12450. Д. 115. Л. 31.

7 Там же. Оп. 12451. Д. 461. Л. 153. 
отсутствие «Пантер», 8 «Тигров», 6 командирских танков и 6 танков-разведчиков, 141 CAУ Stug 3 и 45 САУ «Hornissen» ${ }^{8}$. Таким образом, на тот момент против западных союзников в Италии было собрано 508 единиц тяжелой бронетехники вермахта. В одном из отчетов инспектора бронетанковых войск вермахта значится, что Восточный фронт получил 64 «Пантеры» в июне 1944 года. В то же время в Италию, где вермахту противостояли намного меньшие, чем на Восточном фронте, силы, были отправлены 30 «Пантер». Туда же, в Италию, в июне 1944 г. ушли 27 «Тигров», когда во Францию были отправлены только 6 машин этого типа, кроме того, для Восточного фронта были выделены только 8 «Тигров» ${ }^{9}$.

Большое значение для Италии имели немецкие поставки нефти и нефтепродуктов, а также транзит этой продукции из Румынии через Австрию. Добыча нефти до войны в Италии составляла 13 тыс. т в год. Но ежемесячная потребность только одного итальянского флота составляла 74 тыс. т горючего.

Не менее сложной была ситуация с металлами. Муссолини пошел на крайне непопулярную меру переплавку церковных колоколов, чтобы восполнить потери от прекращения импорта металлов в страну [10, p. 27-61].

Торговля с Италией для немцев была невыгодной, если не считать продукты питания, к которым Германия потеряла доступ из-за морской блокады, это в основном сахар, кофе и чай. Германия продавала режиму Муссолини товары явно по заниженным ценам, приобретая у итальянцев - по завышенным. Это очевидно, если посмотреть хотя бы на стоимость топливного импорта Италии (шел в основном из Германии). В 1939 г. Италия импортировала горючего на сумму 419,5 млн лир объемом 1827161 т, в 1940 г. - 1069443 т

${ }^{8}$ ЦАМО РФ. Ф. 500. Оп. 12451. Д. 461. Л. 6-7.

${ }^{9}$ Там же. Д. 478. Л. 11. 
на сумму 346,9 млн лир, в 1941 г. 234165 т на сумму 132,5 млн лир, в 1942 - 261094 т на сумму 143,8 млн лир ${ }^{10}$. Таким образом, рост цен на ГСМ в Европе несильно сказывался на стоимости его импорта в Италию. Но важно другое - Германия сама испытывала острый дефицит в горючем.

Помимо коммерческих поставок, нацистский режим оказывал Муссолини еще и безвозмездную помощь горючим. Кроме этого, Германия взяла полностью на свой топливный баланс итальянский флот и итальянские силы, действовавшие в Африке при корпусе Роммеля. В 1942 г. Италии была оказана помощь в объеме 122809 т горючего, из них бензина - $56687 \mathrm{~T}^{11}$.

Но больше всего из Германии вытягивали Итальянский флот и Африканский корпус Роммеля. В 1942 г. Германия экспортировала 122,3 тыс. т авиатоплива, или около 9 \% от объема потребления топлива собственной авиацией (значительная часть ушла в Италию), а также 285 тыс. т моторного топлива ${ }^{12}$. Вероятнее всего, большая часть также пошла итальянцам, когда на всю немецкую экономику в 1942 г. пришлось 357 тыс. т моторного топлива. Из 420 тыс. т дизельного топлива для германского флота значительная часть ушла на снабжение итальянских военно-морских сил.

Мы уверены, что спад в производстве гражданской продукции в Германии после 1941 г. во многом был связан с топливным кризисом в национальном хозяйстве. После капитуляции в Германии насчитывалось 70 тыс. тракторов, по нормам того времени, этого было вполне достаточно для обеспечения продовольствием населения. Едва ли проблема с запчастями для сельскохозяйственной техники стояла остро в Германии до осени 1944 г., когда были окончательно утрачены

10 Российский государственный военный архив (РГВА). Ф. 1458. Оп. 53. Д. 32. Л. 22.

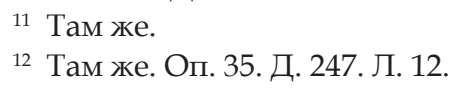


многие машиностроительные мощности в оккупированных странах Европы.

Германская топливная промышленность, работая на грани возможностей уже в начале Второй мировой войны, была обязана делиться, то есть, экспортировать союзникам, в первую очередь Италии, топливо, отнимая его у гражданского сектора, а также у Восточного фронта. Этим, на наш взгляд, в значительной степени объясняется кризис немецкой экономики в 1942-1944 гг. В начале 1941 г. Германия обязалась поставлять в Италию только на нужды ее флота 100000 тонн топлива в месяц (правда, немцы не смогли полностью выполнить это обязательство). К середине октября 1941 г. военно-морские силы Италии получили от немецкой стороны 201000 т топлива, в конце октября того же года итальянцы «выбили» на последний квартал 1941 г. еще 150361 тонну. В первом квартале 1942 г. Германия отправила флоту Италии 126634 т топлива. Эти поставки даже не вносились Министерством народного хозяйства Германии в состав немецкого экспорта, грубо говоря, Военно-морское ведомство Германии взяло Итальянский флот на свое топливное обеспечение. Во втором квартале 1942 г. итальянцы получили для своих военно-морских сил 158764 т немецкого топлива. Даже после поражения под Сталинградом Германия продолжала снабжать итальянский флот, который получил во втором квартале 1943 г. 195 171 т нефти [2, с. 69-70].

Посмотрим на общую картину положения со снабжением топливом Германии в разгар Второй мировой войны (табл.).

Мы считаем, что топливный кризис вооруженных сил Германии был во многом связан с помощью, оказанной Италии, войной в Северной Африке, а также стремлением «дожать» Британскую империю подводной войной. Значительные расходы топлива во втором полугодии 1942 - январе 1943 г. пришлись на 
Таблица

Распределение топливных ресурсов в Германии в 1941-1942 гг.

\begin{tabular}{|l|r|}
\hline \multicolumn{1}{|c|}{\begin{tabular}{c}
\multicolumn{1}{|c|}{ Направления распределения топливных } \\
ресурс
\end{tabular}} & Тыс. тонн \\
\hline $\begin{array}{l}\text { Потребление моторного топлива в Германии } \\
\text { в1942 г. }\end{array}$ & 285 \\
\hline $\begin{array}{l}\text { Экспорт моторного топлива (в основном в } \\
\text { Италию) в1942 г. }\end{array}$ & 283 \\
\hline Экспорт авиатоплива в 1942 г. & 420 \\
\hline $\begin{array}{l}\text { Поставки топлива для итальянского флота } \\
\text { (первое полугодие 1942 года) }\end{array}$ & 6100 \\
\hline $\begin{array}{l}\text { Общие затраты топлива на военно-морские } \\
\text { силы Германии и Италии (только дизельное } \\
\text { топливо) }\end{array}$ & 1400 \\
\hline $\begin{array}{l}\text { Общий объем потребления топлива Герма- } \\
\text { нией в 1942 году }\end{array}$ & 1500 \\
\hline На нужды авиации в 1942 году & 7100 \\
\hline Обеспечение Вермахта моторным топливом & 1744 \\
\hline $\begin{array}{l}\text { Общий объем потребления топлива Герма- } \\
\text { нией в 1941 году }\end{array}$ & \\
\hline $\begin{array}{l}\text { Потребление топлива экономикой Германии } \\
\text { в 1941 году }\end{array}$ & \\
\hline
\end{tabular}

Сост. по: РГВА. Ф. 1458. Оп. 35. Д. 250 (Данные о запасах авиационного бензина для воздушного флота Германии); там же. Д. 247 (Отчет о состоянии со снабжением топливом в Германии).

военную авиацию - в десять раз больше, чем норма потребления топлива всеми задействованными на фронте сухопутными силами нацистской Германии в феврале 1943 г. Но все-таки немалая доля расхода топлива германской авиацией пришлась на Африканский театр военных действий. Известно, что общая потребность группировки Роммеля составляла почти 270 тыс. т топлива только для первых 8 месяцев 1942 г. [1, с.130].

Мы видим, что Германия отправляла в Италию горючее в больших объемах, в обмен получала продук2017. T. 18, № 2. C. $330-356$ 
ты питания по явно завышенным ценам, например, в 1941 г. Италия экспортировала своему главному союзнику 9701 т сыра на сумму в 188 млн лир! $!^{13}$

Тем не менее, и Германия отправляла в Италию продовольствие, в 1940 г. Италия импортировала зерна 690557 т из разных стран. В 1941 г. - 85814 т в основном из Германии, в 1942 г. - 82475 тонн. Только в первом полугодии 1943 г. Италия ввезла из Германии продуктов питания на сумму 597,7 млн лир, но в то же время и в Германию было отправлено продовольствия на сумму в 1462,5 млн, когда как в 1942 - на 3270,9 млн, а в 1941 г. - на 3 474,5 млн. лир ${ }^{14}$.

Даже принимая во внимание, что цены на экспортируемые Италией в Германию продукты питания чаще всего сильно завышались, такой экспорт продовольствия в сочетании с падением заготовок и импорта зерновых не мог не вызвать начала перебоев с продуктами питания в Италии к зиме 1943 года. Судя по данным сбора зерновых по отдельным ведущим аграрным провинциям Италии до и после войны, заготовки зерна в Италии упали в среднем на 10-15 \% к 1943 году [3, с.39]. Тем не менее, мы думаем, свою роль сыграла спекуляция и транспортное нарушение снабжения городов: в Италии резко упало потребление продовольствия гражданским населением, что спровоцировало отставку Муссолини.

\section{Сомнения каудильо и политика Рузвельта на Пиренеях}

Мы знаем, как назывался лидер фашистской партии Италии, - дуче. Но практически не помним про титул испанского диктатора Франко - каудильо. Это вполне объяснимо - Испания официально во Второй мировой войне не участвовала, что касается ее знаменитой пехотной дивизии № 250, то она явля-

\footnotetext{
${ }^{13}$ РГВА. Ф. 1458. Оп. 53. Д. 32. Л. 22.

14 Там же.
} 
лась отрядом фалангистов, которые были зачислены в вермахт.

Кризис монархии в Испании произошел из-за потери Кубы, Филиппин, Пуэрто-Рико и Гуама, которые стали либо американскими территориями, либо зависимыми от США государствами в результате испаноамериканской войны 1898 года. Как и в России, после Крымской войны, в Испании произошла демократизация, что вполне объяснимо тем, что американские солдаты в той войне погибали не от испанских пуль, а в основном от тропических болезней. Однако, в отличие от России, Испания не думала всерьез о реванше. Испанцы ушли без намерений вернуться в свои колонии, обладателями которых они были несколько столетий. Однако Франко вернулся к идее частичной реставрации Испанской империи после победы над республиканцами. Каудильо хотел присоединить Марокко полностью, большая часть этой страны в 1940 году принадлежала Франции. Кроме того, в планы Франко входил захват и других французских колоний в Африке, а также отторжение от Англии Гибралтара. 18 июля 1940 г. Франко открыто заявил, что два миллиона испанских солдат готовы начать возрождение Испанской империи [6, р. 41].

Трения между Гитлером и Франко начались незадолго после торжественного вступления армии националистов в Мадрид. Нацисты требовали от каудильо вернуть 500 млн рейхсмарок, предоставленных Испании в качестве военных займов, - это была стоимость военной помощи Испании со стороны Германии. И произошло недоразумение: Франко это долгом не считал, рассматривая немецкие деньги как вложения в общее дело борьбы с коммунизмом и атеизмом.

Помощь Германии испанским националистам не была, на самом деле, такой масштабной, если не считать эффективного применения пикирующих бомбардировщиков «Штука». Во всяком случае, эта 2017. T. 18, № 2. C. 330-356 
помощь не являлась незаменимой, так как было еще итальянское участие в конфликте, которое было более масштабным. Поэтому Франко больше доверял дуче. Он был готов поддержать Муссолини в его тщетных попытках организовать «второй Мюнхен» в конце августа 1939 г. Но уже во время судетского кризиса Франко заверил западных союзников в своем нейтралитете в случае начала новой большой войны в Европе. Нападение на Польшу было воспринято каудильо отрицательно, так как он считал эту страну главным католическим бастионом против большевизма на Востоке [6, p. 39]. После разгрома Франции положение Испании изменилось, Франко стал искать союза с Гитлером, делая воинственные заявления. Осенью 1940 г. на встрече министра иностранных дел Испании Соньера с Гитлером испанская сторона повторила свои требования по поводу территорий в Африке и насчет Гибралтара, но также выдвинула и другие - обеспечение испанской армии горючим и прочими ресурсами.

Чисто военно-экономические требования Франко не были абсолютно невыполнимыми, Германия вполне могла снабдить Испанию 600-700 тыс. т зерна, а также 200 тыс. т топлива, получив взамен захват Гибралтаpa, без которого Британия едва ли смогла бы продолжать войну. Но вмешалось одно обстоятельство. Англичане атаковали базы французского флота в Дакаре и Мерс-Эль-Кебире. Черчилль хотел лишить режим Виши крупнотоннажных боевых кораблей, которые вполне могли стать частью германских военно-морских сил. В ответ коллаборационистский режим маршала Петена нанес воздушный удар по Гибралтару. Гитлер счел, что наступает час реализации его мечты - создания континентальной антибританской коалиции, частью которой могла стать покоренная его войсками Франция, уже не просто как оккупированная страна, но как полноценный союзник. Гитлер прекрасно понимал, что Франции в таком случае придется сделать 
уступки в Африке в пользу Испании и Италии, но это надо было обставить все так, чтобы французские ультраправые не были бы сильно уязвлены. Эту дипломатическую стратегию Гитлер назвал «grandioser Betrug» (грандиозный обман). С этой целью в октябре 1940 г. германским МИДом были устроены несколько саммитов с участием представителей Виши, Италии и Испании. 23 октября 1940 г. состоялась знаменитая встреча Гитлера с Франко в городке Henday на франко-испанской границе. Протокол этих переговоров не сохранился, но известно, что Франко был настроен достаточно решительно по поводу своих территориальных претензий. Однако и требования Гитлера были странными, он настаивал на передаче Германии французских портов в Марокко - Агадира и Магадора. Однако Испания могла, согласно плану Гитлера, получить французские колонии только в случае, если Франция получала компенсацию за счет отторгнутых от Британии африканских колоний. Франко дал согласие на вступление в войну против Британии, но при условии оказания Испании военной и экономической помощи, то есть, сроки вступления Испании в войну остались неопределенными [6, р. 45]. Хотя, у Гитлера все еще оставалась надежда взять Гибралтар и втянуть Испанию в войну, но по приезде в Берлин после встречи с Франко Гитлера ждала новость - Италия атаковала Грецию. Вскоре последовала другая новость - итальянская армия потерпела поражение, и ее наступление в Греции захлебнулось. Последовала и третья новость - итальянские силы в Африке оказались почти полностью разгромленными Уэйвеллом, в результате чего возникла угроза потери Триполи.

На состоявшейся в середине ноября 1940 г. встрече министра иностранных дел Испании Серрано с Гитлером испанская сторона повторила требование снабжения ее населения и армии продовольствием и горючим, только после этого испанская армия готова 2017. T. 18, № 2. C. 330-356 
была атаковать Гибралтар. Испанские требования означали, что атака на Гибралтар (операция «Феликс») могла быть осуществлена не ранее Рождества 1940 г. На Испанию оказывала влияние морская блокада, которую применили США и Британия, значительная часть активов испанских фирм за рубежом была заморожена. По мнению Канариса, Испания не смогла бы вступить в войну даже зимой 1940-1941 гг., так сильно ее экономику подорвали санкции и недавно завершившаяся гражданская война.

Конечно, Гитлер мог силой заставить Франко вступить в войну, просто пригрозив ему оккупацией. Но здесь опять вмешался случай. Адмирал Канарис, которому было поручено в начале декабря 1940 г. убедить Франко пропустить через Испанию немецкие войска и вступить тем самым в войну, поведал своему старому другу и на то время начальнику генерального штаба генералу Вигону, что Германия настолько отвлечена решением балканских проблем и подготовкой войны с Советским Союзом, что у Гитлера просто нет ресурсов для оккупации Испании [6, p. 48].

Сделал ли этот шаг Канарис, исходя только из антигитлеровских взглядов? Не вдаваясь в подробности вопроса, который лежит несколько за пределами нашего исследования, мы думаем, что дело не в либерализме и англофильстве Канариса. Он просто считал, что открытие еще одного театра военных действий в районе Гибралтара даст нагрузку на экономику Германии и особенно на ее авиационную промышленность. США уже были на грани вступления в войну, и захват Гибралтара немцами мог только ускорить решение Рузвельта напрямую вмещаться в европейский конфликт. К тому же, кораблестроение в Англии и США уже в скором времени могло выйти на уровень, позволяющий обойтись без Гибралтарского пролива. Гитлер это также понимал, поэтому еще летом 1940 г. им была задумана операция по захвату островов Зеленого 
мыса, что должно было парализовать трансатлантическое сообщение между Западной Европой и Северной Америкой. В таком случае США было бы технически сложно вступить в войну. Атака на Гибралтар связывалась Гитлером напрямую с предстоящим вооруженным конфликтом с США [7, р. 298]. И, несомненно, после Гибралтара последовала бы попытка осуществить развертывание военно-морских баз Германии на Канарах, что должно было встретить прямое военное противодействие со стороны США, о чем прямо сказал в сентябре 1940 г. Рузвельт. Канарис являлся бывшим боевым офицером кайзеровского флота, и поэтому прекрасно разбирался в военно-морской стратегии, осознавая, что война в Атлантике одновременно с Англией, ее доминионами и США с отдаленных баз на Канарах не принесет германскому флоту победу, но, скорее всего, он потерпит поражение.

Скорее всего, Франко колебался после встречи с Канарисом. Поэтому в феврале 1941 г. появился отчет его генерального штаба, в котором четко указывались количества и характер военно-экономической помощи для Испании. Риббентроп приказал немецкому послу в Мадриде передать Франко, что всякие переговоры о вступлении Испании в войну прекращены. Не совсем понятна позиция Риббентропа, так как в октябре 1940 г. Гитлер одобрил экономические условия вступления Испании в войну. Отчет испанского генерального штаба не мог быть какой-то новостью, тем более, он не содержал каких-то невыполнимых требований, вполне соответствуя требованиям Франко, выдвинутыми последним 23 октября на встрече с Гитлером.

Решение Риббентропа отчасти согласовывалось с мнением Гитлера, высказанным последним на военном совещании 31 июля 1940 г. Гитлер тогда утверждал, что уступки Испании являются слишком высокой ценой за Гибралтар. Однако, по признанию Гитлера, деваться было некуда, так как маршал Петен катего2017. T. 18 , № 2. C. 330-356 
рически отказался предоставлять германскому флоту базу в Касабланке, которая должна была обеспечиваться из Алжира. Но перед нападением на СССР Гитлер нуждался в прочных позиция в Марокко, опасаясь за свой западный фланг [7, р. 301]. Таким образом, в июле 1940 г. у Гитлера были серьезные сомнения насчет целесообразности участия Испании в войне, он хотел, чтобы его союзником в Африке была вишистская Франция. Однако отказ французских колоний в тропической Африке подчиняться Виши и сделка с эсминцами 2 сентября 1940 г. между США и Британией воздействовали на Гитлера в том направлении, что США, Британия и Франция, включая и маршала Петена, сплели заговор против Германии. В этой связи Гитлером была запланирована операция по захвату Гибралтара с дальнейшей переброской двух дивизий (одна из них танковая) вермахта в Марокко [7, р. 303].

Мы не согласны с Норманом Года, что Гибралтар не рассматривался Гитлером как альтернатива «Морскому льву» или как даже дополнение к этой операции, но как средство предотвращения американского десанта и только. В этой связи, приводимые им заявления Риббентропа, сделанные последним министру иностранных дел графу Чиано 16 сент. 1940 г., что война с Англией уже выиграна [7, p. 303], не могут служить прямым доказательством, что «Феликс» был почти исключительно направлен против США, и что Гитлер всерьез считал Британию побежденной. Заявление Риббентропа являлось хвастовством и частью, как мы думаем, дипломатической игры Гитлера под названием «большого обмана». Из докладов военных экспертов второй половины лета 1940 г. становится ясно, что Британия была далеко не повержена, по мнению немецких военных, а у вторжения на Британские острова были важные объективные препятствия экономического свойства. 
Мнение, что Франко остановило нефтяное эмбарго, является преувеличением. Эмбарго добавило трудностей, но Франко прекрасно осознавал, что в любом случае вступление Испании в войну будет означать прекращение поставок нефти из США, которые было бы почти невозможно осуществлять просто технически из-за британской морской блокады (инициатива нефтяного эмбарго исходила от англичан, которые еще в сентябре 1939 г. перестали пропускать американские суда в Испанию, Рузвельт потом официально присоединился к эмбарго [5, р. 162]). Таким образом, нефтяной вопрос либо изначально заставил Франко отказаться от участия в войне, либо таковой не играл для каудильо реально никакой роли. С 1936 года по сентябрь 1940 года Испания не получила с Запада ни капли нефти, как показывает современный анализ документов, кроме поставок контрабандистов. В сентябре 1940 г. каудильо и Черчилль договорились, и в Испанию стали поставляться почти 51000 т нефти и нефтепродуктов ежемесячно [5, p. 164]. Тогда же Франко изменил тон в общении с Гитлером. Однако, по всей видимости, каудильо не оставлял надежд на то, чтобы получить часть добычи в случае победы «Оси». Однако до переговоров с англичанами о смягчении эмбарго испанцы все-таки получали ограниченные поставки нефти от американской фирмы Техасо, это была контрабанда, с точки зрения Лондона. Однако директор этой американской фирмы Т. Рибер считал иначе, он симпатизировал государствам «Оси» $[5$, р. 166]. По подсчетам экспертов, опубликованным в начале июля 1940 г. в газете «Таймс», благодаря Риберу, Испания под властью франкистов смогла после окончания гражданской войны довести потребление нефти и нефтепродуктов до уровня около 61 тыс. т в месяц [5, p. 167]. Но, как выяснилось после введения в отношении Испании тотального эмбарго, режим Франко почти не делал запасов нефтепродуктов. По признанию 2017. T. 18, № 2. C. 330-356 
министра иностранных дел Суньера, жидкого топлива в Испании оставалось на месяц, что означало голод для ее населения, так как одним из основных источников пропитания испанцев оставались морепродукты. После введения эмбарго Франко обратился к Гитлеру за помощью, запросив 400 тыс. т бензина и 200 тыс. т нефти. Для Германии на тот момент это были огромные объемы, так как люфтваффе вело борьбу с Королевскими ВВС, отсюда практически вся немецкая нефтепереработка была привязана к обеспечению авиации и флота. И после этого Гитлер начал свою дипломатическую игру, прекрасно зная, что экономических «козырей» у него на руках фактически нет. Признания Канариса, сделанные последним в декабре 1940, сделали картину с экономическим состоянием Германии для Франко предельно ясной.

Однако у Гитлера был шанс получить режим Франко в союзники - румынская нефть. К лету 1940 г. Румыния уже склонялась к союзу с Германией. Поражение Франции стало для Бухареста убедительным аргументом в пользу такого альянса. Но отношения нацистского режима с Румынией развивались слишком медленно. Испанцы в июле 1940 г. отправили в Бухарест своего представителя для переговоров по поводу нефтяных поставок. Румынская нефть должна была идти через Черное и Средиземное моря, так определили румынские специалисты. Почему не через Германию по Дунаю, а затем по железной дороге? В Бухаресте еще сильны были политические круги проанглийской ориентации, которые хотели сохранить Румынию нейтральной. Венский арбитраж (отторжение части румынских территорий в пользу Венгрии) сильно поколебал позиции прогерманских политических сил в Румынии. Но на момент переговоров с испанцами румыны находились под впечатлением ввода советских войск в Молдавию и Буковину, Гитлер отреагировал на этот шаг Кремля мягко, убедив Бухарест пойти на 
территориальные уступки. По всей видимости, позиция Гитлера в молдавском вопросе поколебала доверие к нему среди даже румынских ультраправых, поэтому Бухарест сомневался в возможностях в дальнейшем эксплуатировать дунайский маршрут. На наш взгляд, наиболее важным препятствием для экспорта из Румынии стала высокая цена на румынскую нефть [5, р. 170], что стало следствием высокого спроса на этот продукт в Германии. Маршрут через Средиземное море не был столь опасным в 1940 году, учитывая, что им пользовались многие нейтралы, включая на то время и Советский Союз.

Таким образом, отказ режима Франко от вступления в войну стал результатом сложного сплетения обстоятельств, включая в первую очередь провал нефтяных переговоров в Бухаресте. Германия закупала в 1940 г. слишком большие объемы нефти и нефтепродуктов в Румынии, что делало их очень дорогими на международных рынках. Особенно большие партии нефти требовались Германии во втором полугодии 1940 г. из-за Битвы за Англию и начала наиболее жестокой фазы Битвы за Атлантику, получившей название у немецких подводников - «счастливое время». Вступление Испании в войну могло осложнить положение всей Антигитлеровской коалиции, западным союзникам угрожала потеря Африки, откуда они получали значительные сырьевые ресурсы.

Большое значение играли для нацистской Германии поставки вольфрама из Испании. Вольфрамовой теме можно посвятить отдельное исследование. Мы рекомендовали бы в этой связи статью Леонардо Каруана и Ху Рокоффа [4, р. 100-126]. Однако нам кажутся спорными выводы авторов о том, что американские закупки сырья значительно сократили поступления испанского вольфрама в Германию, так как выросли цены на это сырье. Авторы не определили, сколько вольфрама могла принять германская промышлен2017. T. 18 , № 2. C. 330-356 
ность, учитывая иные, не сырьевые, ограничения выпуска. Мы намерены обратиться к этому вопросу в дальнейшем.

\section{Заключение}

В целом, политику западных союзников по отношению к Испании и Италии можно назвать успешной. «Ось» дала трещину в первый же год войны. Однако не нефтяное эмбарго само по себе не позволило Гитлеру привлечь Испанию в качестве союзника на свою сторону. Мы полагаем, что слишком масштабные закупки румынской нефти Германией из-за Битв за Англию и Атлантику не позволили режиму Франко получить доступ к этому сырью. Франко располагал только в испанских колониях в Северной Африке группировкой в семь дивизий. Его слова о готовности двух миллионов испанских солдат прославить свою страну не были пустым хвастовством. Но несколько тысяч британских пилотов и моряков лишили «Ось» такого серьезного аргумента как испанские вооруженные силы.

Что касается Италии, то из-за раннего вступления в войну режим дуче просто не успел перевооружить свою армию. Когда новейшие на тот момент модели танков и самолетов уже были готовы к серийному выпуску, произошел десант на Сицилии - операция «Хаски», сильно ускорившая коллапс фашистского строя в Италии. Так или иначе, но во многом это - заслуга западных союзников, что более трех миллионов итальянских и испанских солдат оказались нейтрализованными в период 1940-1943 годов. Если в первую мировую войну Германия имела такой компенсирующий ресурс как людской потенциал Австро-Венгерской и Османской империй, то во Вторую мировую войну германская армия не получила его адекватной замены в лице итальянской и испанской армий на протяжении всего глобального конфликта. 


\section{Список использованной литературы}

1. Битва за Средиземное море : взгляд победителей : [сб. / сост., пер. и предисл. А. Больных]. - М. : АСТ, 2001. - 700, [2] c.

2. Брагадин М. А. Итальянский флот во Второй мировой войне / М. А. Брагадин ; пер. с англ. - М. : АСТ, 2000. - 352 с.

3. Попов Г. Г. Юго-Западное Средиземноморье как фактор в военной экономике и внешнеэкономической политике нацистской Германии / Г. Г. Попов // Вестник Московского государственного областного университета. - Сер. Исторические науки. - 2014. - № 5. - С. 33-39.

4. Caruana L. A Wolfram in Sheep's Clothing: Economic Warfare in Spain, 1940-1944 / L. Caruana, H. Rockoff // The Journal of Economic History. - 2003. Vol. 63, no. 1. - P. 100-126.

5. Caruana L. An elephant in the garden: The Allies, Spain, and oil in World War II / L. Caruana, H. Rockoff / / European Review of Economic History. - 2007. - Vol. 11, no. 2. - P. 159-187.

6. Detwiler D. S. Spain and the Axis during World War II / D. S. Detwiler // The Review of Politics. - 1971. - Vol. 33, no. 1. - P. 171-183.

7. Goda N. J. W. The Riddle of the Rock: A Reassessment of German Motives for the Capture of Gibraltar in the Second World War / N. J. W. Goda / / Journal of Contemporary History. - 1993. Vol. 28, no. 2. - P. 297-314.

8. Griebling E. K. Broken Fasces: Historical Perceptions. On The Failure Of Fascist Italy : MA Thesis [Electronic recourse] / E. K. Griebling - Hawaii Pacific University, 2009. - 99 p. - Access mode : https://www.hpu.edu/CHSS/History/GraduateDegree/ MADMSTheses/files/2/ERIK_GIREBLINGMADMS_ PROFESSIONAL_PAPER_DEC_2009_UPDATED_COMPLETE. pdf

9. Knox M. Hitler's Italian Allies. Royal Armed Forces, Fascist regime, and the War of 1940-1943 / M. Knox - Cambridge: Cambridge University press, 2003. - 224 p.

10. Sadkovich J. J. Understanding Defeat: Reappraising Italy's Role in World War II / J. J. Sadkovich / / Journal of Contemporary History. - 1989. Vol. 24, no. 1. - P. 27-61.

\section{Информация об авторе}

Попов Григорий Германович - кандидат экономических наук, доцент, департамент экономической теории, Финансовый университет при Правительстве РФ; кафедра эко- 
номики, Московский технологический институт, 119334, г. Москва, Ленинский проспект, 38-a, e-mail: GGPopov2009@ mail.ru.

\section{$\$ \nabla$}

Gregory G. Popov - Ph.D. in Economics, Associate Professor, Department of Economic Theory, Financial University under the Government of the Russian Federation; Department of Economics, Moscow Technology Institute, 38-a, Leninskiy prosp, Moscow, 119334, e-mail: GGPopov2009@mail.ru.

\section{Для цитирования}

Попов Г. Г. Союзники нацистской Германии и разрушение единства «Оси»: страницы экономической истории Второй мировой войны / Г. Г. Попов // Историко-экономические исследования. - 2017. - Т. 18, № 2. - С. 330356. - DOI: 10.17150/2308-2588.2017.18(2).330-356.

\section{7:4.}

Popov G. G. Allies of Nazi Germany and Breakup of the Axis: Pages of the $2^{\text {nd }}$ World War Economic history. Istoriko-ekonomicheskie issledovaniya = Journal of Economic History $\mathcal{E}$ History of Economics, 2017, vol. 18, no. 2, pp. 330-356. DOI: 10.17150/23082588.2017.18(2).330-356. (In Russian). 